\title{
SELEKSI DAN UJI ANTAGONISME TRICHODERMA SPP. ISOLAT TAHAN FUNGISIDA NABATI TERHADAP PERTUMBUHAN PHYTOPHTHORA CAPSICI
}

\author{
Joko Prasetyoı, Efriı \& Radix Suharjoı
}

\begin{abstract}
Screening and testing of isolate of Trichoderma spp. resistant to botanical fungicides on the growth of $P$. capsici. The research was conducted at the Plant Disease laboratory, Plant Protection Department, Faculty of Agriculture, Lampung University from March - November 2007. The aim of the research was to find isolate of Trichoderma spp. resistant to botanical fungicide which still have its capability to inhibit the growth of $P$. capsici. Completely randomized design with three replicates was used in the research. Data collected in this research were isolates of Trichoderma spp. resistant to botanical fungicides and inhibition percentage of isolates of Trichoderma spp. resistant to botanical fungicide on the growth of $P$. capsici. The data were analysed with anova and continued with LSD test at 5\% of significant level. As much as 9 isolates of Trichoderma spp. resistant to botanical fungicide were found. Three isolates of T. viride could survive in the $100 \%$ of tumeric powder (C), east indian galangale powder (A), and clove leaf powder (B). Two isolates of T. harzianum could survive in the $100 \%$ of tumeric powder (A) and clove leaf powder (A). One isolate survived in the $90 \%$ of east indian galangale powder (D). Two isolates of T. koningii also could survive in the $100 \%$ of tumeric powder (A) and clove leaf powder (A). One isolate survived in the $90 \%$ of east indian galangale powder (C). All of the isolates inhibited $P$. capsici. All of the isolates found statistically had the same capability to inhibit the growth of $P$. capsici.
\end{abstract}

Key words: Trichoderma spp., resistance to botanical fungicide, $P$. capsici

\section{PENDAHULUAN}

Penyakit busuk pangkal batang lada merupakan penyakit tular tanah yang berbahaya dan sulit untuk dikendalikan (Erwin, 1983; Anonim, 2006; Semangun, 2000). Beberapa tekhnik pengendalian yang telah direkomendasikan seperti penggunaan varietas tahan, pemberian mulsa, dan penggunaan metalaksil belum memberikan hasil yang memuaskan. Sampai saat ini belum ditemukan adanya varietas lada yang tahan terhadap serangan P. capsici (Sitepu \& Prayitno, 1979; Asnawi \& Hasanah, 1997; Lestari et al., 2000; Setiyono, 2003; Sarma, 2006). Penggunaan metalaksil tidak dapat secara luas dilakukan oleh petani karena efektivitasnya di lapangan belum dapat dirasakan dan memerlukan biaya yang besar. Di samping itu telah banyak dilaporkan bahwa penggunaan metalaksil mendorong terbentuknya ras tahan (Erwin, 1983).

Ginting et al.(1999) melaporkan bahwa Curcuma longa (kunyit), Kaemferia galanga (kencur), dan Eugenia aromatica (cengkeh) secara efektif menekan diameter koloni $P$. capsici secara in vitro. Manohara et al. (1994) juga melaporkan bahwa tepung daun cengkeh dapat menekan pertumbuhan $P$. capsici secara in vitro.
Selain beberapa jenis tumbuhan antagonis, Trichoderma spp. juga mempunyai kemampuan untuk menekan P. capsici serta beberapa Phytophthora yang lain (Malajezuk, 1983; Brasier, 1971; Brasier, 1975; Reeves, 1975). Jamur Trichoderma spp. sangat mudah berkembang pada berbagai media terutama yang berbahan organik tinggi dan juga sangat tahan berbagai keadaan lingkungan yang tidak cocok (Thurston, 1992; Campbell, 1989; Tronsmo, 1996). Selain itu Trichoderma spp. juga diketahui lebih toleran terhadap biosida berspektrum luas (Munnecke, 1972; Thurston, 1992; Tronsmo, 1996). Kondisi tersebut memungkinkan untuk mengaplikasikan Trichoderma spp. dengan fungisida nabati secara bersamaan, sehingga akan diperoleh hasil pengendalian yang optimal.

Permasalahannya adalah kemungkinan besar jamur Trichoderma spp. yang umum digunakan sebagai agen pengendali hayati saat ini akan terhambat perkembangannya oleh fungisida nabati yang diaplikasikan secara bersamaan tersebut. Penelitian ini bertujuan untuk memperoleh isolat Trichoderma spp. yang tahan terhadap fungisida nabati dan masih memiliki kemampuan antagonisme terhadap $P$. capsici. Nantinya isolat Trichoderma spp. tersebut akan dapat 
diaplikasikan bersama-sama dengan fungisida nabati kombinasinya.

\section{METODE PENELITIAN}

Penelitian ini dilaksanakan pada Maret November 2007 di Laboratorium Penyakit Tumbuhan, Jurusan Proteksi Tanaman, Fakultas Pertanian Universitas Lampung. Tata laksana penelitian yang dilakukan dapat diuraikan sebagai berikut.

\section{Pembuatan isolat Trichoderma spp. isolat tahan fungisida nabati}

Pembuatan fungisida nabati. Fungisida nabati kencur, kunyit, dan daun cengkeh dibuat dalam bentuk serbuk. Bahan tanaman dikeringkan pada suhu 50 。C dalam oven selama 4 hari (sampai bobot konstan) lalu digiling dengan disck mill sampai berbentuk serbuk halus lalu disaring dengan saringan 600 mesh. Serbuk yang diperoleh adalah fungisida nabati konsentrasi $100 \%$. Tepung fungisida nabati tersebut disimpan dalam plastik, setiap plastik ukuran $0,5 \mathrm{~kg}$ diisi $15 \mathrm{~g}$ fungisida nabati. Pembuatan konsentrasi 20 - 90\% dilakukan dengan penambahan tepung oat meal; konsentrasi $20 \%$ dapat dibuat dengan melarutkan $20 \mathrm{~g}$ serbuk fungisida nabati dalam tepung oat meal sebanyak $80 \mathrm{~g}$, konsentrasi selanjutnya dapat dibuat dengan cara yang sejalan.

\section{Penyiapan Trichoderma spp. isolat spora tunggal.}

Biakan T. viride, T. harzianum, dan T. koningii pada media PDA masing-masing diambil satu bor gabus dan dimasukkan dalam tabung reaksi yang masing-masing berisi $5 \mathrm{cc}$ air steril. Tabung dirotamikser selama 3 menit supaya spora jamur tersuspensi merata dan terpisah antara spora yang satu dengan spora yang lain. Setiap suspensi spora jamur kemudian diencerkan dari $10_{1}$ sampai $10_{8}$ dengan cara mengambil $1 \mathrm{cc}$ suspensi dan melarutkannya dalam $9 \mathrm{cc}$ air steril sehingga diperoleh tingkat pengenceran 101 sampai 108 . Pada pengenceran $10_{5}, 10_{6}, 10_{7}$, dan $10_{8}$, suspensi masing-masing diambil $0,5 \mathrm{cc}$ dimasukkan dalam cawan petri yang telah berisi media PDA dan diratakan dengan gelas L sehingga diperoleh tebaran spora yang terpisah secara tunggal. Setelah inkubasi selama 2 hari koloni yang tumbuh bulat dan terpisah secara tunggal diambil dengan skalpel untuk dibiakkan pada cawan petri secara tersendiri sehingga pada masing-masing spesies jamur diperoleh 20 isolat spora tunggal. Masing-masing isolat diberi nama dengan angka.
Penyiapan Trichoderma spp. isolat tahan fungisida nabati. Trichoderma spp. pada media PDA (plus 100 streptomisin) (modifikasi dari Domsch et al. 1993) diambil dengan bor gabus sebanyak 5 cakram untuk setiap isolat dan dimasukkan dalam plastik yang telah berisi serbuk fungisida nabati $10 \%$ dengan bahan pembawanya adalah tepung oat meal. Bahan tersebut diinkubasikan selama 3 hari. Setelah inkubasi cakram kultur Trichoderma spp. tersebut kembali dibiakkan pada media PDA dalam cawan petri. Setiap cawan petri diberi 3 cakram diletakkan secara terpisah membentuk segitiga sama sisi. Enam cakram dari setiap spesies Trichoderma spp. yang tumbuh paling cepat dipilih dan diberi nama isolat A, B, C, D, E, dan F. Selanjutnya kultur diadaptasikan pada konsentrasi yang lebih tinggi, sampai konsentrasi tertinggi jamur tersebut tidak dapat tumbuh $(20 \%, 30 \%, 40 \%, 50 \%, 60 \%, 70 \%, 80 \%, 90 \%$ dan $100 \%)$. Setiap spesies dipilih tiga isolat yang paling tahan. Tiga isolat Trichoderma spp. terpilih yang digunakan, merupakan isolat Trichoderma spp. yang dapat hidup di dalam fungisida nabati pada konsentrasi tinggi.

Dari hasil seleksi ini, masing-masing diambil sebanyak tiga koloni dari $T$. viride, $T$. harzianum, dan T. koningii yang masih dapat bertahan pada media yang diberi fungisida nabati konsentrasi tertinggi (1 isolat dari kunyit, 1 isolat dari kencur, dan 1 isolat dari daun cengkeh) diambil sebagai isolat Trichoderma spp. terpilih. Jadi didapatkan 9 isolat jamur Trichoderma spp. yang berasal dari T. viride (3 isolat), T. harzianum (3 isolat), dan T. koningii (3 isolat) yang diuji kemampuan antagonismenya di laboratorium.

\section{Uji antagonisme Trichoderma spp. isolat tahan fungisida nabati}

Dalam rangka menjamin bahwa isolat terpilih masih memiliki kemampuan antagonisme maka perlu dilakukan pengujian antagonisme. Pengujian dilakukan terhadap P. capsici secara in vitro.

Isolasi $\boldsymbol{P}$. capsici dari lada. Isolasi dilakukan untuk mendapatkan isolat jamur penyebab penyakit busuk pangkal batang lada (P. capsici) yang digunakan untuk uji kemampuan antagonis Trichoderma spp. isolat tahan fungisida nabati.

Isolasi dilakukan dari tanah yang diambil dari perakaran lada yang terserang $P$. capsici. Langkah isolasi dilakukan dengan menggunakan metode umpan (apel). Buah apel dilubangi dengan bor gabus. Pada lubang bor dimasukkan tanah dan ditutup dengan isolatif, dan diinkubasikan selama 2 hari. Buah apel dibelah, daerah 
yang mengalami gejala (degradasi) ditanam pada media selektif V-8 (plus 100 ppm streptomisin).

Identifikasi. Langkah identifikasi dilakukan untuk memastikan bahwa koloni jamur yang didapatkan merupakan jamur $P$. capsici, patogen penyebab penyakit busuk pangkal batang lada. Identifikasi dilakukan dengan melakukan pengamatan terhadap koloni yang menunjukkan ciri-ciri P. capsici, baik warna koloni, maupun pengamatan hifa dan sporangium yang menunjukkan ciri khusus $P$. capsici di bawah mikroskop. Pengamatan ciri-ciri $P$. capsici mengacu pada Domsch et al. (1993).

Uji patogenisitas. Uji patogenisitas dilakukan untuk meyakinkan bahwa jamur yang ditemukan merupakan jamur P.capsici yang bersifat patogen. Daun lada yang tidak terlalu tua maupun muda digunakan dalam pengujian ini. Daun didesinfeksi dengan menggunakan alkohol 70\% pada seluruh permukaan atas dan bawah dan dikering-anginkan. Setelah kering, 1 bor gabus biakan murni $P$. capsici yang telah diperoleh ditempelkan pada permukaan bawah daun. Agar biakan murni dapat melekat kuat, maka biakan tersebut dikuatkan dengan di-selotip. Daun tersebut dimasukkan dalam cawan petri yang diberi kapas basah kapasitas lapang. Pengujian dilakukan untuk 10 lembar daun diinokulasi dan 10 lembar daun tanpa inokulasi. Hasil positif ditunjukkan dengan timbulnya gejala nekrotik berwarna coklat kehitaman pada bagian daun yang diinokulasi.

Uji antagonisme. Uji antagonisme dilakukan untuk mengetahui apakah Trichoderma spp. isolat tahan fungisida nabati yang didapatkan masih memiliki kemampuan antagonisme terhadap $P$. capsici setelah pengkondisian di tepung fungisida nabati tersebut.
Pengujian dilaksanakan pada media Potato Dextrose Agar (PDA) dalam cawan petri. Bagian bawah cawan petri diberi tanda garis tengah dengan spidol marker. Kemudian ditentukan sebuah titik yang jaraknya $3 \mathrm{~cm}$ dari tepi petridish sebagai tempat meletakkan inokulum $P$. capsici yang berupa potongan bor gabus, sedangkan dari tepi yang lain juga diukur dengan jarak yang sama sebagai tempat meletakkan potongan bor gabus biakan Trichoderma sp. terpilih (Gambar 1). Kemudian diinkubasikan selama 7 hari. Perlakuannya adalah sembilan isolat Trichoderma spp. tahan fungisida nabati yang diperoleh dengan tiga kali ulangan.

Pengamatan dilakukan tiap hari dengan mengukur jari-jari koloni $P$. capsici yang berlawanan dan menuju ke arah jamur Trichoderma spp. Kemudian daerah penghambatan diukur dengan menggunakan rumus :

Panjang daerah penghambatan $=\quad \frac{r 1 \square r 2}{r 1} \times 100 \%$

dengan

r1 = Jari-jari koloni $P$. capsici yang berlawanan arah dengan jamur Trichoderma sp.

r2 = Jari-jari koloni jamur $P$. capsici menuju ke arah jamur Trichoderma sp.

Data persen penghambatan kemudian dianalisis dengan menggunakan sidik ragam, dan dilanjutkan dengan uji Beda Nyata Terkecil (BNT) dengan tingkat kepercayaan $5 \%$.

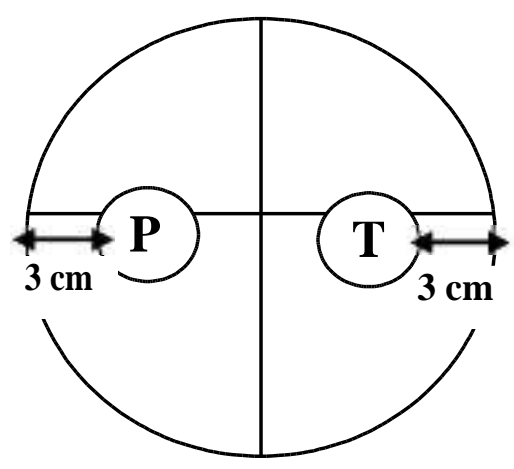

Gambar 1. Cara peletakan inokulum P. capsici dan Trichoderma spp.

Keterangan : $\mathbf{P}=$ biakan $P$. capsici, $\mathbf{T}=$ biakan Trichoderma spp. 


\section{HASIL DAN PEMBAHASAN}

Isolat jamur Trichoderma tahan fungisida nabati. Hasil pengamatan terhadap pengkondisian di ketiga tepung fungisida nabati untuk ketiga jenis jamur Trichoderma menunjukkan bahwa pada konsentrasi $20 \%, 30 \%, 40 \%$ dan 50\%, keenam isolat untuk setiap jenis jamur Trichoderma masih dapat bertahan hidup dan tumbuh. Pada jamur T. viride, kematian isolat dimulai pada konsentrasi $60 \%$ pada tepung kencur sebanyak 1 isolat (F). Pada tepung daun cengkeh dimulai pada konsentrasi $90 \%$ sebanyak 1 isolat (A). Pada tepung kunyit, keenam isolat mampu bertahan hidup sampai konsentrasi $100 \%$. Pada T. harzianum, kematian isolat pada tepung kencur dimulai pada konsentrasi $70 \%$ sebanyak empat isolat (A, C, E dan F). Pada tepung kunyit, kematian isolat dimulai pada konsentrasi $80 \%$ sebanyak 1 isolat (B). Pada tepung daun cengkeh, kematian isolat terjadi pada konsentrasi $100 \%$ sebanyak 3 isolat (B, E dan F). Pada jamur T. koningii, kematian isolat dimulai pada tepung kencur sebanyak 2 isolat (B dan E). Pada tepung kunyit dan daun cengkeh, keenam isolat mampu bertahan hidup pada konsentrasi $100 \%$ (Tabel 1).

\section{Penentuan 3 isolat terbaik jamur Trichoderma spp.}

Tabel 1 memperlihatkan bahwa terdapat beberapa isolat jamur Trichoderma spp. yang mampu bertahan hidup pada fungisida nabati dengan konsentrasi 100\%, namun begitu ada pula isolat yang tidak mampu bertahan hidup pada tingkat konsentrasi tersebut. Secara rinci hal itu dapat diuraikan sebagai berikut.

Trichoderma viride . Hasil pengkondisian memperlihatkan bahwa keenam isolat $T$. viride mampu bertahan hidup pada tepung kunyit dengan konsentrasi $100 \%$. Pada tepung kencur, 4 isolat (A, C, D dan E) mampu bertahan hidup pada konsentrasi $100 \%$ dan 2 isolat lainnya (B dan F) tidak mampu tumbuh atau mati. Sedangkan pada tepung daun cengkeh, 5 isolat (B, C, $\mathrm{D}, \mathrm{E}$ dan $\mathrm{F}$ ) mampu bertahan hidup pada konsentrasi $100 \%$, dan 1 isolat lainnya (A) tidak mampu bertahan hidup atau mati.

Trichoderma harzianum. Sebanyak 2 isolat jamur $T$. harzianum (A dan F) mampu bertahan hidup pada tepung kunyit dengan konsentrasi 100\%, sedangkan 4 isolat lainnya (B, C, D dan E) tidak mampu bertahan hidup atau mati. Keenam isolat ternyata tidak mampu bertahan hidup pada tepung kencur dengan konsentrasi $100 \%$. Pada konsentrasi $90 \%$, hanya terdapat 1 isolat yang mampu bertahan hidup (D), sedangkan isolat lainnya (A, B, C, E dan F) tidak mampu bertahan hidup atau mati. Pada tepung daun cengkeh konsentrasi $100 \%$, terdapat 3 isolat (A, C dan D) yang mampu bertahan hidup, dan 3 isolat lainnya (B, E, dan F) tidak mampu bertahan hidup atau mati.

Trichoderma koningii. Keenam isolat jamur $T$. koningii ternyata mampu bertahan hidup pada tepung kunyit dan tepung daun cengkeh dengan konsentrasi $100 \%$. Namun, keenam isolat tersebut tidak mampu bertahan hidup pada tepung kencur dengan konsentrasi 100\%. Pada konsentrasi 90\%, 3 isolat T. koningii (A, $\mathrm{C}$, dan D) mampu bertahan hidup, sedangkan 3 isolat lainnya (B, E dan F) tidak mampu bertahan hidup atau mati.

Dari hasil pengkondisian tersebut, kemudian dari tiap spesies jamur Trichoderma diambil masing-masing 1 isolat dari tepung kunyit, 1 isolat dari tepung kencur dan 1 isolat dari tepung daun cengkeh. Hasil pemilihan isolat terbaik yang didasarkan pada diameter pertumbuhan koloni dan kemampuan tumbuh masingmasing isolat pada pengkondisian kunyit, kencur dan cengkeh dengan konsentrasi tertinggi didapatkan 9 isolat terbaik.

T. viride. Pada tepung kunyit didapatkan isolat $\mathrm{C}$, pada tepung kencur isolat A dan untuk tepung daun cengkeh didapatkan isolat B. Ketiga isolat itu mampu bertahan hidup pada konsentrsi $100 \%$.

T. harzianum. Untuk tepung kunyit dan daun cengkeh didapatkan isolat A. Isolat A tersebut mampu bertahan hidup pada konsentrasi $100 \%$ di tepung kunyit dan daun cengkeh. Untuk tepung kencur didapatkan isolat $\mathrm{D}$ pada konsentrasi $90 \%$. Pengambilan isolat dari konsentrasi 90\% tersebut karena keenam isolat $T$. harzianum tidak mampu bertahan hidup pada konsentrasi $100 \%$.

T. koningii. Pada tepung kunyit dan daun cengkeh didapatkan isolat A. Isolat A tersebut mampu bertahan hidup pada konsentrasi $100 \%$ di tepung kunyit dan daun cengkeh. Untuk tepung kencur didapatkan isolat $\mathrm{C}$ pada konsentrasi $90 \%$. Pengambilan isolat dari konsentrasi 90\% tersebut karena ke enam isolat $T$. koningii tidak mampu bertahan hidup pada konsentrasi $100 \%$. Untuk lebih jelasnya, hasil uraian di atas dapat dilihat pada Tabel 2.

Terdapatnya isolat-isolat yang tahan terhadap fungisida nabati pada hasil penelitian ini adalah seiring dengan penelitian sebelumnya (Munnecke, 1972; Thurston, 1992; Tronsmo, 1996; Benitez, 2004). Telah 


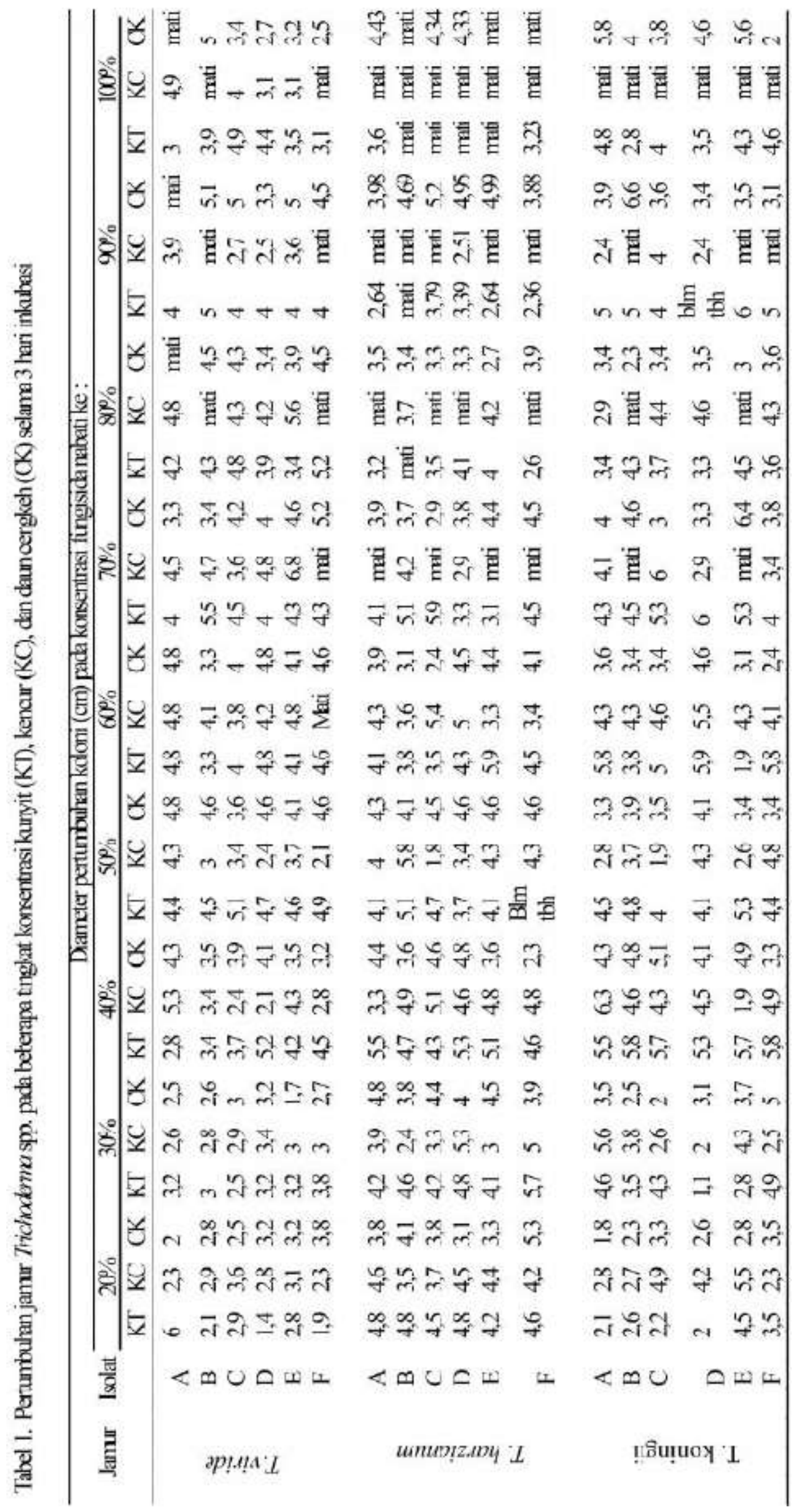


Tabel 2. Sembilan isolat terbaik pada masing-masing jenis fungisida nabati

\begin{tabular}{ccccc}
\hline No & $\begin{array}{c}\text { Jenis } \\
\text { Trichoderma } \text { spp. }\end{array}$ & Kode isolat & Jenis fungisida nabati & $\begin{array}{c}\text { Konsentrasi } \\
\text { fungisida nabati }\end{array}$ \\
\hline 1 & T. viride & C & Tepung kunyit & $100 \%$ \\
2 & & A & Tepung kencur & $100 \%$ \\
3 & & B & Tepung daun cengkeh & $100 \%$ \\
& & & & \\
4 & T. harzianum & A & Tepung kunyit & $100 \%$ \\
5 & & D & Tepung kencur & $90 \%$ \\
6 & & A & Tepung daun cengkeh & $100 \%$ \\
& & & & \\
7 & T. koningii & A & Tepung kunyit & $100 \%$ \\
8 & & C & Tepung kencur & $90 \%$ \\
9 & & A & Tepung daun cengkeh & $100 \%$ \\
\hline
\end{tabular}

diketahui bahwa Trichoderma spp. dapat bertahan pada kondisi lingkungan yang tidak menguntungkan termasuk adanya bahan kimia seperti fungisida. Hal ini disebabkan karena Trichoderma spp. dapat memproduksi senyawasenyawa (enzim) yang dapat mendetoksifikasi pengaruh fungisida tertentu. Telah diketahui Trichoderma spp. banyak menghasilkan enzim chitinase dan glukanase, diduga enzim ini tidak hanya menyerang dinding sel patogen, tetapi juga dapat memecah ikatan gugus fungsional fungisida nabati, sehingga tidak bersifat toksik lagi terhadap Trichoderma spp. Ketahanan terhadap senyawa toksik dapat juga berhubungan dengan adanya sistem transport ABC pada strain-strain Trichoderma (Harman et al., 2004) Isolat yang terpilih, mampu bertahan pada konsentrasi tertinggi mengindikasikan bahwa isolat tersebut mampu memproduksi senyawa tersebut dalam jumlah yang lebih besar dibandingkan dengan isolat yang tidak dapat bertahan.

\section{Uji antagonisme Trichoderma isolat tahan fungisida nabati}

Isolat Phytophthora capsici. Hasil isolasi dari tanah di sekitar tanaman lada sakit didapatkan koloni jamur berwarna putih lembut pada permukaan media dengan pola bintang dan diduga sebagai jamur Phytophthora capsici, penyebab penyakit busuk pangkal batang lada. Untuk lebih menyakinkan dugaan tersebut, jamur yang didapatkan tersebut kemudian diidentifikasi lebih lanjut dengan mengamati di bawah mikroskop. Hasil pengamatan menunjukkan bahwa jamur tersebut memiliki hifa yang tidak bersekat, berbentuk hialin dengan sporangium berbentuk buah pir (Gambar 2). Ciri-ciri tersebut sesuai dengan ciri-ciri jamur $P$. capsici yang dikemukakan oleh (Domsch et al., 1993). Hal ini membuktikan bahwa jamur yang ditemukan tersebut merupakan jamur $P$. capsici, penyebab penyakit busuk pangkal batang lada.

Uji patogenesitas. Hasil uji patogenesitas menunjukkan hasil yang positif. Pada daerah permukaan daun lada, tempat diletakkan biakan murni jamur yang ditemukan tersebut timbul gejala nekrosis, berwarna coklat kehitaman dengan pingir yang bergerigi (Gambar 3). Hal ini sesuai dengan gejala serangan jamur $P$. capsici pada lada menurut Semangun (2000). Kenyataan ini menunjukkan bahwa jamur yang ditemukan tersebut merupakan isolat $P$. capsici yang bersifat patogen. Dengan demikian isolat ini dapat digunakan sebagai bahan untuk uji penghambatan jamur Trichoderma spp. strain tahan terhadap fungisida nabati secara in vitro.

Uji Antagonisme. Hasil pengujian menunjukkan bahwa ke-sembilan isolat Trichoderma spp. yang diuji tidak kehilangan kemampuan antagonismenya terhadap $P$. capsici. Pertumbuhan jamur $P$. capsici dapat dihambat oleh Trichoderma spp. (Gambar 4).

Hasil pengamatan menunjukan bahwa kesembilan isolat Trichoderma spp. mempunyai kemampuan antagonis yang hampir sama untuk menghambat pertumbuhan $P$. capsici. Hal itu terlihat dari hasil uji statistik yang menunjukkan tidak adanya beda nyata (Tabel 3).

Tabel 3 menunjukkan bahwa pengkondisian di dalam fungisida nabati tersebut tidak berpengaruh fatal terhadap kemampuan antagonisme jamur Trichoderma spp. tersebut. Dalam pengertian bahwa isolat-isolat tersebut masih memiliki kemampuan antagonisme. Isolat 


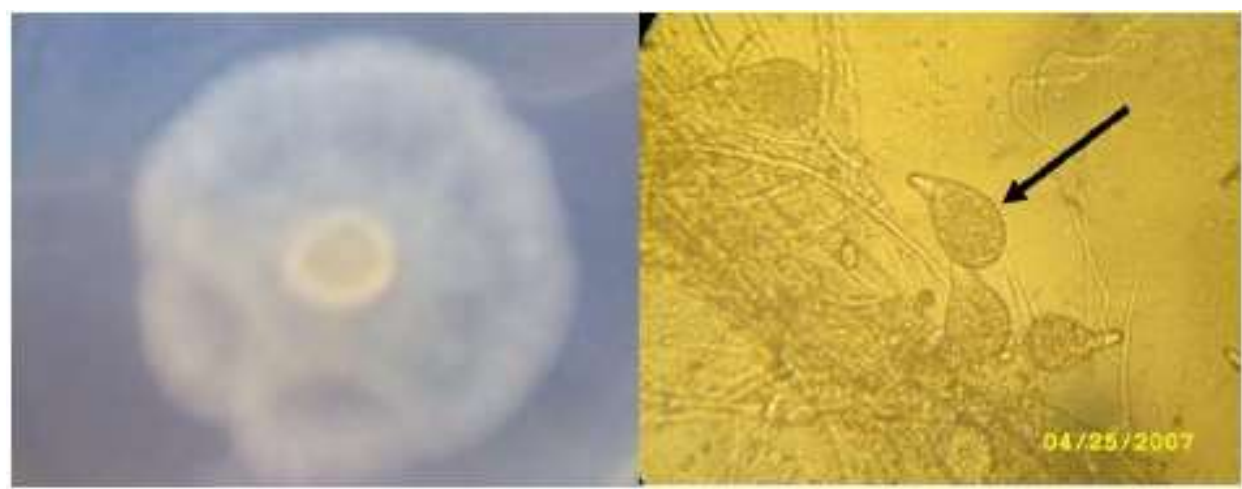

Gambar 2. Koloni jamur P. capsici yang ditemukan. A. Koloni dengan pola bintang. B. pengamatan sporangium di bawah mikroskop (anak panah).

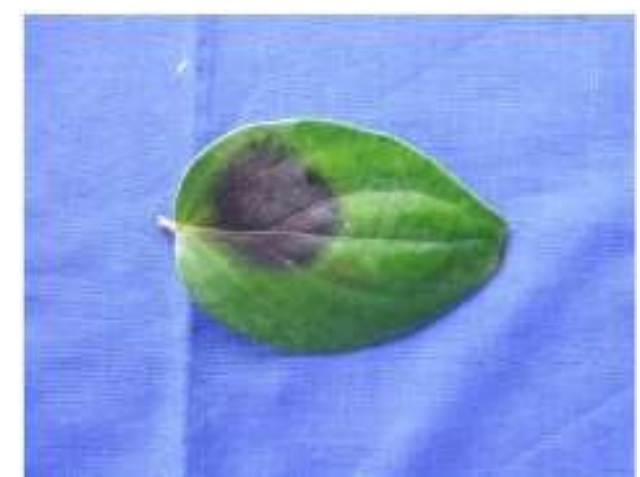

Gambar 3. Hasil uji patogenesitas pada daun lada

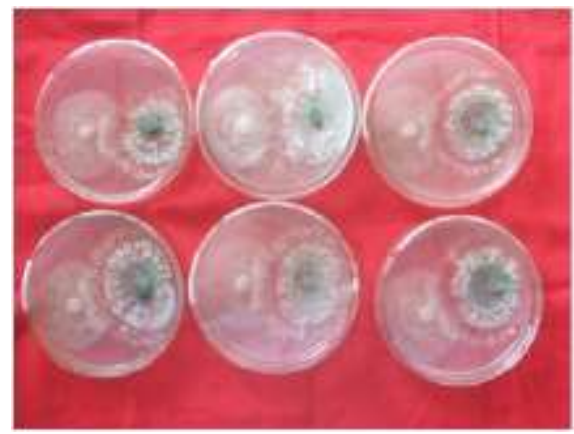

Gambar 4. Uji antagonisme Trichoderma spp. terhadap P. capsici dengan metode kultur ganda.

Trichoderma spp. yang diuji memiliki kemampuan penghambatan bervariasi yang terendah $19,028 \%$ dan yang tertinggi $29,762 \%$ Kenyataan ini sangat mungkin terjadi, karena memang jamur Trichoderma spp. sangat mudah berkembang dan juga sangat tahan terhadap berbagai keadaan lingkungan yang tidak cocok (Thurston, 1992; Campbell, 1989; Tronsmo, 1996). Trichoderma spp. juga diketahui lebih toleran terhadap biosida berspektrum luas (Munnecke, 1972; Thurston, 1992; Tronsmo, 1996). Kemampuan adaptasi pada biosida berspektrum luas diduga karena Trichoderma spp. dapat memroduksi senyawa-senyawa yang dapat mendetoksifikasi biosida tersebut. Dari pengujian tersebut juga diketahui bahwa antarisolat yang diuji tidak berbeda nyata dalam kemampuan penghambatan terhadap $P$. capsici. 
Tabel 3. Kemampuan penghambatan beberapa isolat Trichoderma spp. terhadap diameter koloni Phytophthora capsici

\begin{tabular}{|c|c|c|}
\hline Perlakuan & Isolat & Persentase penghambatan $(\%)$ \\
\hline T. viride Isolat Tahan Kunyit & $\mathrm{C}$ & 19,220a \\
\hline T. viride Isolat Tahan Kencur & A & $21,128 \mathrm{a}$ \\
\hline T. viride Isolat Tahan Cengkeh & $\mathrm{B}$ & $19,028 \mathrm{a}$ \\
\hline T. harzianum Isolat Tahan Kunyit & A & $20,278 \mathrm{a}$ \\
\hline T.harzianum Isolat Tahan Kencur & $\mathrm{D}$ & $29,762 \mathrm{a}$ \\
\hline T. harzianum Isolat Tahan Cengkeh & $\mathrm{A}$ & $21,688 \mathrm{a}$ \\
\hline T. koningii Isolat Tahan Kunyit & A & $22,262 \mathrm{a}$ \\
\hline T. koningii Isolat Tahan Kencur & $\mathrm{C}$ & 24,693 a \\
\hline T. koningii Isolat Tahan Cengkeh & A & $21,310_{a}$ \\
\hline
\end{tabular}

Keterangan: angka dalam kolom yang diikuti oleh huruf yang sama tidak berbeda nyata menurut uji BNT 5\%

\section{SIMPULAN}

1. Terdapat 9 isolat Trichoderma spp. tahan fungisida nabati (tepung kunyit, kencur dan daun cengkeh) terbaik. Tiga isolat dari $T$. viride ( 1 isolat dari tepung kunyit konsentrasi $100 \%$ (C), 1 isolat dari tepung kencur konsentrasi 100\% (A) dan 1 isolat dari tepung daun cengkeh konsentrsi 100\% (B), tiga isolat dari $T$. harzinum (1 isolat dari tepung kunyit konsentrasi 100\% (A), 1 isolat dari tepung kencur konsentrasi 90\% (D) dan 1 isolat dari tepung daun cengkeh konsentrsi 100\% (A) dan tiga isolat di T. koningii (1 isolat dari tepung kunyit konsentrasi 100\% (A), 1 isolat dari tepung kencur konsentrasi 90\% (C) dan 1 isolat dari tepung daun cengkeh konsentrsi $100 \%$ (A).

2. Kesembilan isolat Trichoderma spp. tahan fungisida nabati tersebut masih memiliki kemampuan antagonisme terhadap P.capsici dengan kemampuan antagonisme antar isolat yang tidak berbeda nyata.

\section{SANWACANA}

Ucapan terima kasih kami sampaikan kepada Ditjend DIKTI atas dana hibah bersaing yang diberikan sehingga penelitian ini dapat terlaksana. Terima kasih juga kami ucapkan kepada Yuni Mayasari, Citra Puspita Sari, Rita Santia Dewi danAhmad Subhan atas bantuan dan kerjasama tim yang baik serta semua pihak yang telah membantu dalam penelitian ini.

\section{DAFTAR PUSTAKA}

Anonim. 2006. Phytophtora capsici. <http: // www. extento. hawaii. edu/ Kbase/ crop/Type/ p_capsi.htm diakses tanggal 26 Maret 2006>.

Asnawi, R. \& Hasanah. 1997. Uji Ketahanan Beberapa Varietas Lada terhadap Phytophthora palmivora (Bult). Jurnal Fitopatologi Vol (01): 18-22.

Benitez, T., A.M. Rincon, M.C. Limon, \& A.C. Codon. 2004. Biocontrol mechanism of Trichoderma strains. International Microbiology 7: 249-260.

Brasier, C.M. 1971. Introduction of Sexual Reproduction in Single $\mathrm{A}_{2}$ Isolates of Phytophthora spesies by Trichoderma viride. Nature (London) New Biol. 231-283.

Brasier, C.M. 1975. Stimulation of Sex Organ formation of Phytophthora by Antagonistic Spesies of Trichoderma, I. The Effect In Vitro. New Phytol. 74: 183-194. 
Capmbell, R. 1989. Biological Control of Microbial Manohara, D.D., Wahyuno, \& Sukamto. 1994.

Plant Pathogens. Cambridge University Press.

New York-Melbourne Sydney.

Domsch, K.H., W. Gams, \& T. Anderson. 1993. Compendium of Soil Fungi. VOl 1. IHW-Verlag, Bert-Brech.

Erwin, D.C. 1983. Variability Within and Among Species of Phytophthora. Pages: 149-165 in Phytophthora Its Bilogy, Taxonomy, Ecology, and Pathology. D.C. Erwin, S. Bartnicki-Garcia, and P.H. Tsao (eds.). St. Paul, Minnesota.

Ginting, C. , D.R.J. Sembodo, H. Susanto, \& M. Prama Yufdi. 1999. Kemampuan Beberapa Tepung Tumbuhan dalam Menekan Pertumbuhan Phytophthora capsici dari Tanaman Lada. Hal: 512-518 dalam Prosiding Kongres Nasional XV Dan Seminar Ilmiah PFI, Purwokerto.

Harman, G.E., C.R. Howell, A. Viterbo, I. Chet, \& M. Lorito. 2004. Trichoderma speciesopportunistic, aviruplent plant symbionts. Nature Review 2: 43-56.

Lestari, E.G., D. Sukmadjaja, I. Mariska, Hobir, M. Tombe, M. Kosmiatin, Y. Rusyadi \& S. Rahayu. 2000. Perbanyakan In Vitro dan Pengujian Lanjutan pada Nomor-Nomor Harapan Panili dan Lada yang Tahan Penyakit. Proseding Seminar hasil Penelitian Rintisan dan Bioteknologi. <http: // www.ndobiogen.or.id/ terbitan/prosiding/pros2000/Endang_1.pdf diakses tanggal 26 Maret 2006>.

Malajezuk, N. 1983. Microbial Antagomism to Phytophthora. Pages: 197-218 in Phytophthora Its Biology, Taxonomi, Ecolgy, and Pathology. D.C. Erwin, S. Bartnicki-Garcia, and P.H. Tsao (eds.). St. Paul, Minnesota.
Pengaruh Tepung dan Minyak Cengkeh terhadap Phytophthora, Rigidoporus, dan Sclerotium. Hal.: 19-27 dalam Prosiding Seminar Hasil Penelitian dalam Rangka Pemanfaatan Pestisida nabati Badan Penelitian dan Pengembangan Pertanian. Bogor.

Munnecke, D.E. 1972. Factors effecting the Efficacy of Fungicides in Soil. Ann. Rev. Phytopathol. 10: 375-397.

Reeves, R.J. 1975. Behaviour of Phytophthora cinnanomi Rands In Different Soil and Water Regimes. Soil. Biol. Biochem. 7: 19-24.

Sarma, Y.R. 2006. Biological Control for Phytophthora Foot Root Rot of Black Pepper, Piper nigrum, In India. <http: // www. bspp. org. uk/ icpp98/ 5.2/ 5S.html> diakses tanggal 3 Maret 2006.

Semangun, H. 2000. Penyakit-penyakit Tanaman Perkebunan di Indonesia. Gajah Mada University Press. Yogyakarta.

Setiyono, R.T. 2003. Status Pemuliaan Tanaman Lada. Perkembangan Teknologi TRO XV (2) : 1-10.

Sitepu, D. \& S. Prayitno. 1979. Uji Resistensi Varietas Lada terhadap Phytophthora palmivora secara in vitro. Pembert. LPTI 35: 15-21.

Thurston, H.D. 1992. Sustainable Practices for Plant Disease Management in Traditional Farming System. Oxford \& IBH Publishing Co. Pvt. Ltd.

Tronsmo, A. 1996. Trichoderma harzianum in Biological Control of Fungal Disease. In R. Hall. Principles and Practice of Managing Soil Borne Pathogens. APS Press. Minnesota. 